\title{
PENGARUH KEPEMILIKAN INSTITUSIONAL, KOMPETENSI DEWAN KOMISARIS DAN KUALITAS AUDITOR PADA NILAI PERUSAHAAN
}

\author{
Cok Istri Ratna Sari Dewi ${ }^{1}$ \\ Ni Made Dwi Ratnadi ${ }^{2}$ \\ Maria M. Ratna Sari ${ }^{3}$ \\ ${ }^{1,2,3}$ Fakultas Ekonomi dan Bisnis Universitas Udayana (Unud), Bali, Indonesia \\ e-mail: coknanaa@gmail.com
}

\begin{abstract}
ABSTRAK
Nilai perusahaan yang tinggi akan meningkatkan kekayaan para pemegang saham. Semakin tinggi harga saham maka akan semakin tinggi juga nilai suatu perusahaan. Umumnya untuk meraih nilai perusahaan yang tinggi, para pemegang saham akan meyerahkan pengelolaannya kepada para profesional. Penelitian ini bertujuan menguji pengaruh kepemilikan institusional, kompetensi dewan komisaris dan kualitas auditor pada nilai perusahaan, khususnya pada perusahaan manufaktur.Data yang digunakan adalah data sekunder eksternal berupa laporan keuangan dan laporan tahunan perusahaan manufaktur yang terdaftar di Bursa Efek Indonesia tahun 2012-2015.Pemilihan sampel menggunakan purposive sampling dan diperoleh 48 perusahaan dengan jumlah pengamatan selama 4 tahun.Teknik analisis data yang digunakan adalah analisis regresi berganda.Hasil pengujian menunjukkan bahwa kepemilikan institusional, kompetensi dewan komisaris dan kualitas auditor berpengaruh positif pada nilai perusahaan.
\end{abstract}

Kata kunci : kepemilikan institusional, kompetensi dewan komisaris, kualitas auditor, nilai perusahaan.

\begin{abstract}
High firm value will increase the prosperity of shareholders. The higher the stock price, the higher the firm value could be. Generally investors will hand over its management to the professionals to achieve the company's goal which is to increase the firm values. This study aims to examine the influence of institutional ownership, the competence of board of commissioners and the quality of auditor on firm values. The analyzed data is secondary data, taken from financial statements and annual reports of companies that listed in Indonesia Stock Exchange from 2012-2015. The sample selection determined by using purposive sampling technique, 48 companies were acquired. Multiple linear regression techniques were used to analyze the data.The results showed that institutional ownership, the competence of board of commissioners and the quality of auditor have positive effects on firm values.
\end{abstract}

Keywords : institutional ownership, the competence of board of commissioners, the quality of auditor, firm values. 


\section{PENDAHULUAN}

Tujuan utama perusahaan adalah untuk memakmurkan para pemilik perusahaan atau pemegang saham yang dapat dicapai dengan memaksimalkan nilai perusahaan, dengan asumsi bahwa pemilik perusahaan atau pemegang saham akan makmur bila kekayaannya meningkat. Nilai perusahaan yang tinggi akan menunjukkan kemakmuran pemilik perusahaan atau pemegang saham, oleh sebab itu nilai perusahaan yang tinggi telah menjadi keinginan para pemilik perusahaan atau pemegang saham pada umumnya. Nilai perusahaan dapat diukur dari berbagai aspek diantaranya adalah dengan menggunakannilai bukuekuitas dan nilai pasar ekuitas.Nilai buku ekuitas adalah nilai ekuitas yang didasarkan pada pembukuan perusahaan, sedangkan nilai pasar ekuitas adalah nilai ekuitas berdasarkan harga pasar yang sering dikaitkan dengan harga saham perusahaan di pasar modal. Nilai perusahaan berdasarkan nilai buku ekuitas dihitung dengan mengurangkan nilai buku total aset dan total kewajiban. Subekti, et al. (2010) berpendapat bahwa nilai buku memiliki kelemahan-kelemahan, yaitu rawan terjadi praktik manipulasi transaksi keuangan dan dijadikan dasar bagi manajemen perusahaan untuk mengelola labanya dalam rangka mencapai target laba yang telah ditetapkan.Adanya tuduhan unsur manipulasi terhadap nilai buku perusahaan telah terjadi pada perusahaan publik di Indonesia. PT Kimia Farma Tbk. melakukan manipulasi berupa oversated dalam menilai persediaan barang jadi dan mencatat nilai penjualan, yang mengakibatkan overstated laba pada laba bersih untuk tahun yang berakhir 31 Desember 2001 (Bapepam, 2002). 
Sementara itu, nilai perusahaan berdasarkan nilai pasar ekuitas dapat dihitung dengan menggunakan rumus harga pasar saham perusahaan dikalikan dengan jumlah saham yang beredar.Koetin (1997) menyatakan bahwa pengukuran nilai perusahaan yang didasarkan pada harga pasar saham memiliki beberapa kelemahan.Pertama, terdapat unsur permainan yang dilakukan oleh spekulator untuk mendapatkan keuntungan dalam waktu singkat sehingga harga pasar saham dapat naik ataupun merosot tajam.Spekulator ini umumnya adalah investor yang memiliki orientasi jangka pendek.Kedua, harga pasar saham cenderung dipengaruhi oleh tekanan psikologi atau tindakan irasional investor dalam berinvestasi.Fenomena ini terjadi pada PT Primarindo Asia Infrastruktur Tbk. yang telah melakukan praktik manipulasi pasar atas saham pada tahun 2002 (Bapepam, 2002).

Nilai perusahaan yang diukur berdasarkan nilai buku ekuitas dan nilai pasar ekuitas kurang representatif. Oleh karena itu, para investor dapat mempertimbangkan alat ukur lain untuk mengukur kinerja perusahaan lainya yang digunakan sebagai dasar dalam menilai suatu perusahaan. Rasio Tobin's Q merupakan salah satu pengukuran kinerja perusahaan yang dapat digunakan, yaitu dengan menggabungkan nilai buku ekuitas dan nilai pasar ekuitas. Rasio ini diukur dengan menambahkan nilai pasar ekuitas dan nilai buku total kewajiban, kemudian dibagi dengan nilai buku total aset. Rasio Tobin's Q merupakan alat ukur yang lebih teliti karena memberikan gambaran yang tidak hanya pada aspek fundamental, tetapi juga sejauh mana pasar menilai perusahaan dari berbagai aspek yang dilihat oleh pihak luar termasuk investor 
(Hastuti, 2005). Nilai Tobin's Q yang tinggi menunjukkan bahwa perusahaan tersebut memiliki prospek pertumbuhan yang baik.Selain itu,perusaah dengan nilai Tobin's Q yang tinggi biasanya menunjukkan bahwa perusahaan tersebut memiliki reputasi yang kuat dimata investor.Perusahaan dengan nilai Tobin's Q yang rendah umumnya berada pada industri yang sangat kompetitif atau industri yang mulai mengecil (Sukamulja dan Sukmawati, 2004).

Proses memaksimalkan nilai perusahaan dalam praktiknya sering kali menyebabkan terjadinya konflik kepentingan antara pengelola (agen) dan pemegang saham (prinsipal). Jensen dan Meckling (1976) berargumen bahwa konflik keagenan terjadi karena adanya pemisahan kepemilikan dan pengendalian.Nilai perusahaan akan turun sebagai akibat dari terjadinya konflik keagenan. Nilai perusahaan yang rendahakan mempengaruhi kekayaan dari pemegang saham sehingga umumnya para pemegang saham akan melakukan pengawasan atas perilaku manajemen. Berdasarkan teori agensi, perbedaan kepentingan antara pengelola (agen) dan pemegang saham (prinsipal) ini umumnya disebut sebagai konflik keagenan (agency conflict). Struktur kepemilikan saham dapat memengaruhi kinerja perusahaan dalam mencapai tujuan perusahaan yaitu memaksimalkan nilai perusahaan, sebab dengan adanya kontrol yang dimiliki oleh para pemegang saham, pengawasan atas kinerja manajemen akan meningkat.Struktur kepemilikan saham dalam perusahaan umumnya meliputi kepemilikan institusional, kepemilikan manajerial, serta kepemilikan saham oleh individual atau publik. Kepemilikan institusional merupakan metode pengawasan yang berasal dari sisi eksternal yaitu institusi, sehingga perusahaan yang 
bersangkutan akan menjadi lebih memperhatikan kepentingan pemegang saham institusi.Kepemilikan saham yang dimiliki oleh investor instutisional akan mempermudah proses monitoring sehingga dapat mengurangi tindakan-tindakan manajemen yang tidak diinginkan, misalnya manajemen laba yang dapat merugikan perusahaan. Ismiyanti dan Mamduh (2004) menyatakan bahwa semakin tinggi kepemilikan institusional maka pengawasan eksternal terhadap perusahaan juga akan semakin meningkat. Perusahaan akan lebih terawasi dengan adanya pengawasan dari pihak eksternal sehingga tujuan perusahaan dapat tercapai.Tingkat kepemilikan institusional yang tinggi akan dapat menghindarkan perusahaan dari perilaku opportunistic manajemen, sebab pihak investor institusional memiliki usaha pengawasan yang besar atas perusahaan yang dimilikinya.

Beberapa penelitian empiris mengenai pengaruh kepemilikan institusional terhadap nilaiperusahaan telah banyak dilakukan sebelumnya, seperti yang ditunjukkan dalam penelitian Sukirni (2012) membuktikanbahwa kepemilikan institusional berpengaruh positif secara signifikan terhadapnilai perusahaan.Begitu pula dengan penelitian yang dilakukan oleh Nuraina (2012) menunjukkan bahwa kepemilikan institusional dan ukuran perusahaan berpengaruh signifikan terhadap nilai perusahaan.Borolla (2011) dalam pengujiannya menunjukkan bahwa struktur kepemilikan institusional berpengaruh positif signifikan terhadap nilai perusahaan.Hasil penelitian tersebut mendukung teori agency cost yang menyatakan bahwa struktur kepemilikan merupakan salah satu mekanisme yang efektif untuk mengatasi masalah keagenan yang terjadi akibat perbedaan kepentingan antara pihak 
agen dan prinsipal. Kepemilikan institusional dapat mengawasi kinerjatim manajemen secara lebih efektif dan nantinya dapat meningkatkan nilai perusahaan. Investor institusional juga akan berusaha melakukan berbagai usaha positif guna meningkatkan nilai perusahaan miliknya. Berbeda dengan penelitian yang dilakukan Sofyaningsih dan Hardiningsih (2011) serta Wahyudi dan Pawestri (2006) menemukan bahwa kepemilikan institusional tidak berpengaruh terhadap nilai perusahaan.Kepemilikan institusional dapat mengurangi agency conflickarena dengan konsentrasi kepemilikan yang tinggi akan mendorong pemegang saham pada posisi yang kuat untuk mengendalikan manajemen secara efektif. Maka dari itu, diharapkan manajemen akan terdorong untuk bertindak sesuai dengan kepentingan pemegang saham sehingga dapat terhindar dari hal-hal yang merugikan perusahaan. Disamping itu, melalui usaha-usaha yang positif, investor institusional akan berusaha untuk meningkatkan nilai perusahaan yang dimilikinya (Haruman, 2008).

Mengawasi kebijakan dan pelaksanaan kebijakan perusahaan yang dilakukan oleh pihak manajemen merupakan tugas dari dewan komisaris. Kompetensi dewan komisaris merupakan hal yang penting untuk diperhatikan, walaupun tidak mengharuskan seseorang untuk masuk dalam dunia bisnis, akan lebih baik jika dewan komisaris berkompetensi di bidang ekonomi dan bisnis. Kompetensi dewan komisaris merupakan faktor yang sangat penting, karena dewan komisaris yang memiliki pemahaman yang baik atas operasi bisnis dapat mereview laporan keuangan secara efektif (Lanfranconi dan Robertson, 2002).Latar belakang pendidikan yang dimiliki oleh anggota dewan berpengaruh terhadap pengetahuan yang dimiliki.Dewan 
komisaris yang memiliki pengetahuan di bidang ekonomi dan bisnis dapat melakukan pengendalian secara efektif, sehingga dapat meningkatkan kualitas pelaporan keuangan. Pelaporan keuangan yang baik dan transparan dapat mengundang respon positif dari para investor, sehingga nilai perusahaan akan meningkat. Dengan demikian, dewan komisaris dapat mengelola bisnis dan mengambil keputusan yang tepat berdasarkan pengetahuan ekonomi yang dimiliki yang nantinya bisa memberikan hasil yang maksimal untuk para pemegang saham.

Cadbury, et al. (1993) menyatakan bahwa faktor pengalaman penting sebagai unsur kompetensi bagi dewan komisaris.Pengalaman dan pengetahuan khusunya dibidang ekonomi dan bisnis yang dimiliki dewan komisaris dapat meningkatkan pengawasan sehingga dapat terhindar dari kecurangan dalam pelaporan keuangan.Ratnadi dan Ulupui (2016) mengatakan bahwa dewan komisaris yang memiliki kompetensi dibidang akuntansi/keuangan merupakan atribut kuatnya tata kelola perusahaan, sehingga menyebabkan meningkatnya konservatisme akuntansi, sebagai dasar untuk membantu mereka dalam peran pengawasan. Tingkat pengawasan yang maksimal dapat menciptakan kinerja direksi menjadi lebih efektif dan efisien sehingga dapat meningkatkan kinerja keuangan perusahaan. Seiring dengan meningkatnya kinerja keuangan perusahaan maka investor akan merespon baik perusahaan dengan menghargai nilai saham perusahaan lebih tinggi bila dibandingkan dengan nilai bukunya. Penelitian Roma (2012) menguji pengaruh kompetensi dewan komisaris, proporsi dewan komisaris independen, dan frekuensi rapat dewan komisaris terhadap nilai perusahaan.Hasil penelitian membuktikan bahwa kompetensi 
dewan komisaris berpengaruh positif terhadap probabilitas perusahaan untuk dinilai lebih tinggi oleh investor.Penelitian Darmadi (2013) menemukan bahwa latar belakang pendidikan dari anggota dewan berpengaruh terhadap kinerja perusahaan, pada tingkat tertentu.Wiwik, et al. (2007) menemukan bahwa kompetensi dan independensi dewan komisaris berpengaruh positif terhadap pelaksanaan good corporate governance. Namun penelitian Kusumastuti, et al. (2007) yang menguji pengaruh board diversity terhadap nilai perusahaan dalam perspektif corporate governance membuktikan bahwa latar belakang pendidikan ekonomi dan bisnis tidak berpengaruh terhadap nilai perusahaan.

Sampai saat ini tidak ada definisi yang seragam mengenai kualitas auditor karena kesulitan mengukur kualitas auditor, banyak penelitian empiris yang menggunakan beberapa proksi atau dimensi untuk mengukur kualitas auditor.Kualitas audit merupakan kemampuan auditor untukmenemukan kesalahan atau kecurangan dalam sistem akuntansi dan tekanan dari klien untukmenutup buku secara selektif walaupun kecurangan telah ditemukan (DeAngelo, 1981). Menurut Christiawan (2003), kualitas audit dapat ditentukan oleh dua hal yaitu independensi dan kompetensi. Kompetensi auditor dapat ditunjukkan dengan ukuran kantor akuntan publik (Mayangsari, 2004). Penelitian Ardiana (2014) menunjukkan bahwa terdapat pengaruh positif ukurankantor akuntan publik terhadap nilai perusahaan, tingkat kompetensi dari auditor yang tinggi akan meningkatkan kredibilitas laporan keuangan, yang nantinya akan berpengaruh terhadap harga saham perusahaan. Semakin tinggi harga saham perusahaan maka nilai suatu perusahaan juga akan 
semakin tinggi. Namun hasil penelitian Juliardi (2013) dan Dewata, et al. (2015) menunjukkan bahwa kualitas audit tidak berpengaruh signifikan terhadap nilai perusahaan yang diaudit kantor akuntan publik besar (KAP Big 4)maupun kantor akuntan publik (KAP non Big 4). Hasil penelitian Afiah (2015) menunjukkan bahwa masih banyak akuntan publik lokal yang belum memenuhi standar kompetensi internasional karena pasar jasa akuntansi masih dikuasai oleh kantor akuntan publik besar (KAP Big 4) sehingga kebanyakan kantor akuntan publik lokal belum mampu menyediakan program untuk meningkatkan kualitas para akuntannya.

Berdasarkan teori signaling, perusahaan akan memberikan sinyal kepada para investor atas keberhasilan atau kegagalan perusahaan yang dijalankannya. Dalam hal ini, kualitas auditor dapat menjadi sinyal positif ataupun negatif.Hussainey (2009) menyatakan bahwa kualitas laporan keuangan yang diaudit oleh kantor akuntan besar lebih berkualitas tinggi dibandingkan dengan kualitas laporan keuangan yang diaudit oleh kantor akuntan publik biasa, sehingga umumnya investor akan bereaksi positif bila laporan keuangan suatu perusahaan diaudit oleh KAP Big 4.Watts dan Zimmerman (1986) menyatakan bahwa faktor ukuran KAP berpengaruh terhadap kualitas audit. KAP yang besar dianggap lebih mampu dalam melakukan pengawasan terhadap auditor secara individual dan mendeteksi opportunistic behavior.Laporan keuangan yang diaudit oleh kantor akuntan publik besar (KAP Big 4) lebih dipercaya para investor karena auditor akan lebih berhati-hati dalam melakukan proses audit dalam mendeteksi kecurangan untuk mempertahankan kredibilitas dan reputasinya. Perusahaan yang mempunyai keyakinan bahwa perusahaan tersebut mempunyai 
prospek yang baik kedepannya akan cenderung mengkomunikasikan berita tersebut terhadap para investor (Ross, 1977). Semakin tinggi kualitas auditor maka akan meningkatkan kredibilitas dari laporan keuangan, yang nantinya berpengaruh terhadap harga saham perusahaan. Harga saham yang tinggi akan meningkatkan nilai perusahaan. Adapun kantor akuntan publik di Indonesia yang berafiliasi dengan KAP Big 4 (berdasarkan alphabet) adalah sebagai berikut: 1) Deloitte Touche Tohmatsu (Deloitte) yang berafiliasi dengan Osman Bing Satrio \& Eny; 2) Ernst \& Young (EY) yang berafiliasi dengan Purwantono, Sungkoro \& Surja; 3) Klynveld Peat Marwick Goerdeler (KPMG) yang berafiliasi dengan Siddharta Widjaja \& Rekan; 4) PricewaterhouseCoopers (PwC) yang berafiliasi dengan Tanudiredja, Wibisana, Rintis \& Rekan.

Penelitian ini bertujuan menguji pengaruhkepemilikan institusional, kompetensi dewan komisaris dan kualitas auditor pada nilai perusahaan di Indonesia, khususnya perusahaan manufaktur. Pemilihan perusahaan-perusahaaan publik yang masuk kategori perusahaan manufaktur ini didasarkan pada pertimbangan akan homogenitas dalam aktivitas produksinya dan kelompok industri ini yang relatif lebih besar jika dibandingkan dengan kelompok industri lain di Bursa Efek Indonesia. Berdasarkan latar belakang dan kajian pustaka yang mendukung penelitian, pengembangan hipotesis penelitian yang diajukan oleh peneliti yaitu :

$\mathrm{H}_{1}$ : Kepemilikan institusional berpengaruh positif pada nilai perusahaan.

$\mathrm{H}_{2}$ : Kompetensi dewan komisaris berpengaruh positif pada nilai perusahaan.

$\mathrm{H}_{3}$ : Kualitas auditor berpengaruh positif pada nilai perusahaan. 


\section{METODE PENELITIAN}

Variabel independen adalah variabel yang memengaruhi atau yang menjadi sebab perubahan atau timbulnya variabel dependen (Sugiyono, 2014:59).Variabel dependen adalah variabel yang dipengaruhi atau yang menjadi sebab akibat adanya variabel bebas. Variabel dependen dalam penelitian ini adalah nilai perusahaan.Nilai perusahaan diukur dengan rasio Tobin's Q. Nilai perusahaan yang di ukur dengan rasio Tobin's Q dapat dihitung dengan rumus sebagai berikut:

$$
\text { Tobin's } \mathrm{Q}=\frac{\mathrm{MVE}+\mathrm{DEBT}}{\mathrm{TA}} \ldots
$$

Keterangan :

Tobin's $\mathrm{Q}=$ nilai perusahaan

MVE = nilai pasar ekuitas $(\mathrm{MVE}=$ closing price saham $\mathrm{x}$ jumlah saham yang beredar)

DEBT = total kewajiban

TA $\quad=$ total aset

Variabel independen dalam penelitian ini adalah kepemilikan institusional, kompetensi dewan komisaris dan kualitas auditor.Kepemilikan institusional merupakan persentase dari kepemilikan saham oleh institusi dibagi dengan jumlah saham beredar.Kompetensi dewan komisaris diukur dengan menggunakan jumlah dewan komisaris yang berlatar belakang pendidikan dalam bidang ekonomi dan bisnis dibagi total dewan komisaris. Latar belakang pendidikan dapat berasal dari lulusan fakultas ekonomi bergelarsarjana muda, sarjana, magister, dan doktor dari universitas dalam negeri maupunluar negeri atau pernah mengikuti pelatihan atau 
pendidikan non-formal yangberkaitan dengan kompetensi keuangan dan administrasi bisnis.Kualitas auditor dalam penelitian ini diukur dengan variabel dummy dimana angka 1 merupakan nilai diberikan bila perusahaan diaudit oleh KAP Big 4 dan bernilai 0 bila perusahaan diaudit oleh KAP non Big 4 .

Populasi yang digunakan dalam penelitian ini adalah seluruh perusahaan manufaktur yang terdaftar di Bursa Efek Indonesia periode 2012-2015.Alasan dipilihnya perusahaan manufaktur karena perusahaan manufaktur merupakan jenis usaha yang bergerak disektor riil yang memiliki jumlah perusahaan yang paling banyak dibandingkan jenis usaha lain yang terdiri dari beberapa industri. Meskipun terdiri dari berbagai macam industri, perusahaan manufaktur memiliki karakteristik yang serupa.Periode 2012-2015 yang digunakan dalam penelitian ini karena merupakan data terbaru untuk melanjutkan penelitian terdahulu dan sebagai acuan untuk penelitian selanjutnya.Pengambilan sampel dalam penelitian ini menggunakan metode nonprobability sampling dengan teknik purposive sampling, yaitu teknik sampling dengan menggunakan pertimbangan dan batasan tertentu sehingga sampel yang dipilih relevan dengan tujuan penelitian. Adapun kriteria-kriteria yang dimaksud adalah sebagai berikut: 1) Perusahaan manufaktur yang terdaftar di Bursa Efek Indonesia (BEI) selama periode 2012-2015; 2) Menerbitkan laporan keuangan tahunan secara lengkap dan telah diaudit oleh auditor independen untuk periode 2012-2015; 3) Memiliki data mengenai kepemilikan institusional selama periode pengamatan; 4) Terdapat informasi mengenai latar belakang pendidikan anggota dewan komisaris pada laporan tahunan (annual report); 5) Laporan keuangan 
perusahaan dengan tahun buku yang berakhir pada periode 31 Desember.

Teknik analisis data dalam penelitian ini dilakukan dengan uji statistik menggunakan regresi linear berganda.Sebelum menggunakan model regresi linear berganda dalam menguji hipotesis, maka terlebih dahulu dilakukan pengujian asumsi klasik agar model regresi yang diperoleh dari metode kuadrat terkecil nantinya menghasilkan penaksir bias linear terbaik (Best Linear Unbiased Estimator atau $B L U E$ ) sehingga hasil perhitungan dapat diinterpretasikan dengan efisien dan akurat. Model regresi dikatakan $B L U E$ apabila memenuhi semua asumsi klasik (Ghozali, 2014: 173).Pengujian asumsi klasik yang dilakukan dalam penelitian ini adalah uji normalitas, uji multikolinearitas, uji autokorelasi dan uji heteroskedastisitas.Pengujian hipotesis dalam penelitian ini dilakukan dengan pengujian analisis koefisien determinasi $\left(\mathrm{R}^{2}\right)$, pengujian secara parsial (uji statistik $\mathrm{t}$ ) dan pengujian model (uji statistik F).

Model regresi linear berganda ditunjukkan oleh persamaan sebagai berikut:

$$
\text { Tobin's } \mathrm{Q}=\alpha+\mathrm{b}_{1} \mathrm{KI}+\mathrm{b}_{2} \mathrm{KDK}+\mathrm{b}_{3} \mathrm{KA}+\mathrm{e}
$$

\section{Keterangan :}

$$
\begin{aligned}
& \text { Tobin's } \mathrm{Q}=\text { nilai perusahaan } \\
& \alpha \quad=\text { konstanta } \\
& \mathrm{b}_{1} \quad=\text { koefisien regresi kepemilikan institusional } \\
& \mathrm{b}_{2} \quad=\text { koefisien regresi kompetensi dewan komisaris } \\
& \mathrm{b}_{3} \quad=\text { koefisien regresi kualitas audit } \\
& \text { KI } \quad=\text { kepemilikan institusional } \\
& \text { KDK = kompetensi dewan komisaris } \\
& \text { KA }=\text { kualitas auditor } \\
& \text { e } \quad=\text { standar eror }
\end{aligned}
$$




\section{HASIL DAN PEMBAHASAN}

\section{Analisis Statistik Deskriptif}

Berdasarkan kriteria sampel dan prosedur penyampelan yang telah dilakukan, diperoleh 48 perusahaan dengan 192 sampel penelitian dengan jumlah pengamatan selama 4 tahun pengamatan.

Tabel 1.

Analisis Statistik Deskriptif

\begin{tabular}{lcccc}
\hline \multicolumn{1}{c}{ Variabel } & Minimum & Maksimum & Rata-Rata & $\begin{array}{c}\text { Standar } \\
\text { Deviasi }\end{array}$ \\
\hline Kepemilikan Institusional & 37,11 & 99,09 & 74,55 & 14,52 \\
Kompetensi Dewan Komisaris & 0,00 & 1,00 & 0,64 & 0,27 \\
Kualitas Auditor & 0,00 & 1,00 & 0,30 & 0,46 \\
Tobin's Q & 0,33 & 1,94 & 0,95 & 0,28 \\
\hline
\end{tabular}

Sumber: data diolah, 2016

Berdasarkan Tabel 1 menunjukkan bahwa rata-rata kepemilikan institusional adalah sebesar 74,55 dengan standar deviasi sebesar 14,52. Hal ini berarti bahwa ratarata sebesar 74,55 persen saham perusahaan sampel dimiliki oleh institusi atau lembaga seperti perusahaan asuransi, bank, perusahaan investasi, dan kepemilikan institusi lainnya.Nilai minimum kepemilikan institusional yaitu sebesar 37,11 persen dimiliki oleh PT. Nipress Tbk pada tahun 2012 dan 2013, sedangkan nilai maksimum kepemilikan institusional yaitu sebesar 99,09 persen dimiliki oleh PT. Sekar Laut Tbk pada tahun 2013 .

Nilai minimum variabel kompetensi dewan komisaris adalah 0,00, sedangkan 
nilai maksimum kompetensi dewan komisaris adalah 1,00.Rata-rata kompetensi dewan komisaris adalah sebesar 0,64 dengan standar deviasi sebesar 0,27. Hal ini berarti bahwa rata-rata dewan komisaris yang mempunyai kompetensi di bidang ekonomi dan bisnis dalam sampel perusahaan adalah sebesar 64 persen, menunjukkan bahwa sebagian besar perusahaan memiliki dewan komisaris yang mempunyai kompetensi di bidang ekonomi dan bisnis. Namun ada perusahaan yang dewan komisarisnya tidak memiliki kompetensi dibidang ekonomi dan bisnis, ditunjukkan dengan nilai minimum 0 persen ( 3 perusahaan) dan ada juga perusahaan yang seluruh dewan komisarisnya berkompeten dibidang ekonomi dan bisnis yang ditunjukkan dengan nilai maksimum 100 persen (20 perusahaan).

Kualitas auditor diukur dengan menggunakan variabel dummy yaitu nilai 1 untuk perusahaan yang diaudit oleh KAP Big 4, dan nilai 0 untuk perusahaan yang diaudit oleh KAP nonBig 4. Nilai minimum kualitas auditor adalah 0,00, sedangkan nilai maksimumnya adalah 1,00. Rata-rata kualitas auditor adalah sebesar 0,30 dengan standar deviasi sebesar 0,46, yang bahwa rata-rata perusahaan sampel memilih untuk menggunakan jasa KAP non Big 4. Hal ini ditunjukkan dengan sebanyak 33 perusahaan atau 68,75 persen menggunakan jasa KAP non Big 4, sedangkan 15 perusahaan atau 31,25 persen menggunakan jasa KAP Big 4 dari total sampel perusahaan yaitu sebanyak 48 perusahaan.

Besarnya nilai perusahaan yang ditunjukkan dalam rasio Tobin's Q memiliki nilai minimum sebesar 0,33 pada PT. JAPFA Tbk tahun 2015 dan nilai maksimum sebesar 1,94 pada PT. Astra Otoparts Tbk tahun 2012. Nilai Tobin's Q yang lebih 
besar dari 1 menunjukkan bahwa perusahaan tersebut memiliki peluang investasi yang lebih baik dan memiliki potensi pertumbuhan yang lebih tinggi.Nilai perusahaan yang diukur dengan Tobin's Q dalam penelitian ini menunjukkan nilai rata-rata sebesar 0,95 (kurang dari 1) dengan standar deviasi sebesar 0,28.Hal ini berarti ratarata peluang investasi dan potensi pertumbuhan perusahaan belum dapat dikatakan baik.

\section{Uji Asumsi Klasik}

Pengujian asumsi klasik perlu dilakukan agar hasil prediksi analisis regresi tidak bias serta tidak melanggar asumsi-asumsi metode kuadrat terkecil, yaitu BLUE (Best Linear Unbiased Estimator). Uji asumsi klasik yang dilakukan dalam penelitian ini meliputi uji normalitas, uji multikolinearitas, uji autokorelasi dan uji heteroskedastisitas.Hasil pengujian asumsi klasik dalam penelitian ini disajikan pada Tabel 2.

\section{Tabel 2.}

Hasil Uji Asumsi Klasik

\begin{tabular}{|c|c|c|c|c|c|}
\hline \multirow{2}{*}{ Variabel } & \multicolumn{2}{|c|}{ Multikolinearitas } & \multirow{2}{*}{$\begin{array}{c}\text { Heteroskedastisitas } \\
\text { Sig. }\end{array}$} & \multirow{2}{*}{$\begin{array}{c}\text { Normalitas } \\
\text { Asymp. Sig. } \\
\text { (2-tailed) }\end{array}$} & \multirow{2}{*}{$\begin{array}{c}\text { Autokorelasi } \\
\text { Durbin- } \\
\text { Watson } \\
\end{array}$} \\
\hline & Tolerance & VIF & & & \\
\hline Kepemilikan Institusonal & 0,99 & 1,01 & 0,21 & \multirow{3}{*}{0,20} & \multirow{3}{*}{1,97} \\
\hline Kompetensi Dewan Komisaris & 0,92 & 1,09 & 0,58 & & \\
\hline Kualitas Auditor & 0,92 & 1,08 & 0,47 & & \\
\hline
\end{tabular}

Berdasarkan hasil pengujian pada Tabel 2, nilai koefisien Asymp.Sig. (2tailed) sebesar 0,20 lebih besar dari 0,05.Data dinyatakan berdistribusi normal apabila koefisien Asymp.Sig. (2-tailed) lebih besar dari 0,05, sehingga dapat disimpulkan 
bahwa variabel dalam penelitian ini berdistribusi normal.Hasil pengujian juga menunjukkan bahwa variabel independen memiliki koefisien tolerance lebih besar dari 0,10 , dan VIF kurang dari 10. Hal ini berarti bahwa tidak terdapat gejala multikolinear dari model regresi yang dibuat, sehingga model tersebut layak digunakan untuk memprediksi.

Model dikatakan bebas dari autokorelasi jika nilai Durbin-Watsonlebih besar dari nilai $d u$ pada tabel. Berdasarkan hasil pegujian pada Tabel 5.3 diatas, nilai Durbin-Watson sebesar 1,97 dan dibandingkan dengan nilai tabel menggunakan nilai signifikansi 5 persen, untuk $\mathrm{n}=192$, dan jumlah variabel independen sebanyak 3 $(\mathrm{k}=3)$, maka $d l$ (batas luar) $=1,74$ dan $d u($ batas dalam $)=1,79$. Oleh karena itu nilai Durbin-Watson 1,97 lebih besar dari $(d u)$ 1,79 dan kurang dari $3-1,79(3-d u)$, maka dapat disimpulkan bahwa model regresi tidak mengandung gejala autokorelasi. Hasil pengujian juga menunjukkan bahwa nilai signifikansi variabel independen masing-masing sebesar $0,21,0,58$ dan 0,47 atau lebih besar dari 0,05.Hal ini menunjukkan bahwa model yang dibuat tidak mengandung gejala heteroskedastisitas, sehingga layak digunakan untuk memprediksi.

Berdasarkan pengujian asumsi klasik yang telah dilakukan, maka dapat disimpulkan bahwa data penelitian ini bebas dari gejala multikolinearitas, autokorelasi, heteroskedastisitas, dan data residualnya berdistribusi normal.Sehingga data penelitian ini dapat dilanjutkan untuk diolah dengan analisis regresi berganda.

\section{Hasil Analisis Regresi Berganda}


Analisis pengaruh kepemilikan institusional, kompetensi dewan komisaris, dan kualitas auditor pada nilai perusahaan (Tobin's Q) di uji dengan menggunakan analisis regresi liniear berganda.Hasil analisis disajikan pada Tabel 3.

\section{Tabel 3.}

Hasil Analisis Regresi Berganda

\begin{tabular}{|c|c|c|c|}
\hline Variabel & $\begin{array}{c}\text { Koefisien } \\
\text { Regresi }(\boldsymbol{\beta})\end{array}$ & $\mathbf{t}$ & Sig. \\
\hline (Constant) & 0,479 & 4,543 & 0,000 \\
\hline Kepemilikan Institusional & 0,004 & 3,295 & 0,001 \\
\hline Kompetensi Dewan Komisaris & 0,171 & 2,382 & 0,018 \\
\hline Kualitas Auditor & 0,121 & 2,834 & 0,005 \\
\hline \multicolumn{4}{|l|}{ Adjusted R Square : 0,127 } \\
\hline Signifikansi F $\quad: 0,000$ & & & \\
\hline
\end{tabular}

Berdasarkan hasil uji analisis regresi berganda, dapat dibentuk persamaan regresi linear seperti berikut.

Tobin's $\mathrm{Q}=0,479+0,004 \mathrm{KI}+0,171 \mathrm{KDK}+0,121 \mathrm{KA}$

Dari persamaan regresi linear berganda diatas maka dapat diketahui nilai konstanta sebesar 0,479 menyatakan bahwa jika variabel kepemilikan institusional, kompetensi dewan komisaris dan kualitas auditor dianggap konstan (bernilai 0), maka nilai perusahaan yang tercermin dalam rasio Tobin's Q adalah sebesar 0,479 . Hal ini berarti sebelum dipengaruhi oleh ketiga variabel independen, perusahaan telah memiliki nilai positif sebesar 0,479 . 
Koefisien regresi kepemilikan institusional adalah sebesar 0,004 dengan nilai signifikansi sebesar 0,001 (kurang dari 0,05), maka $\mathrm{H}_{1}$ diterima.Hal ini berarti terdapat pengaruh variabel kepemilikan institusional pada perubahan variabel nilai perusahaan (Tobin's Q).Perubahan variabel kepemilikan institusional (KI) mempunyai nilai koefisien regresi sebesar 0,004. Koefisien bertanda positif, hal ini berarti bahwa setiap peningkatan rasio kepemilikan institusional sebesar 1 persen akan mengakibatkan kenaikan nilai perusahaan (Tobin's Q) sebesar 0,004 persen (dengan catatan variabel independen lainnya konstan). Hasil penelitian ini sejalan dengan hasil penelitian Sukirni (2012), Nuraina (2012), dan Borolla (2011).Berdasarkan teori agensi, perbedaan kepentingan antara agen dan prinsipal dapat memunculkan konflik karena manajer perusahaan cenderung untuk mengejar tujuan pribadi daripada memaksimalkan kesejahteraan pemegang saham.Kepemilikan institusional efektif dalam mengatasi masalah agensi yang terjadi akibat adanya perbedaan kepentingan antara agen dan prinsipal.Kepemilikan institusional akan dapat mengawasi kinerja manajemen secara efektif agar nantinya dapat meningkatkan nilai perusahaan. Pemilik institusional juga akan berusaha melakukan usaha-usaha yang positif dalam rangka meningkatkan nilai perusahaan miliknya. Hal tersebut akan mempermudah proses monitoring sehingga perusahaan akan terhindar dari hal-hal yang dapat merugikan perusahaan.

Tingkat kepemilikan institusional yang tinggi akan mendorong para pemegang saham pada posisi yang kuat untuk mengendalikan manajemen secara lebih efektif sehingga masalah agensi dapat dikurangi. Dengan adanya pengawasan 
pihak eksternal maka jalannya perusahaan dapat lebih diawasi sehingga dapat mencapai tujuan perusahaan.Dengan kepemilikan institusional yang tinggi maka tingkat pengendalian yang dilakukan dari sisi ekternal terhadap perusahaan akan semakin kuat. Hal tersebut akan mengurangi agency cost sehingga nilai perusahaan juga akan semakin meningkat.

Koefisien regresi kompetensi dewan komisaris adalah sebesar 0,171 dengan nilai signifikansi sebesar 0,018 (kurang dari 0,05), maka $\mathrm{H}_{2}$ diterima.Hal ini berarti terdapat pengaruh antara variabel kompetensi dewan komisaris pada perubahan variabel nilai perusahaan (Tobin's Q).Koefisien bertanda positif yang artinya jika variabel independen lainnya konstan dan kompetensi dewan komisaris mengalami kenaikan 1 satuan, maka nilai perusahaan akan meningkat sebesar 0,171. Semakin banyak jumlah dewan yang memiliki kompetensi di bidang ekonomi dan bisnis, maka nilai perusahaan akan semakin meningkat. Probabilitas perusahaan untuk dinilai lebih tinggi oleh investor akan meningkat apabila perusahaan tersebut dipimpin oleh dewan komisaris yang berkompetensi di bidang ekonomi dan bisnis. Dewan komisaris yang berkompeten dapat mempertimbangkan keputusan berdasarkan pengetahuan ekonomi dan bisnis yang dimilikinya. Dewan komisaris akandapat lebih berhati-hati dalam mengambil keputusan yang bertujuan untuk memperketat pengawasan terhadap kinerja dewan direksi. Tingkat pengawasan yang maksimal dapat menciptakan kinerja direksi menjadi lebih efektif dan efisien sehingga dapat meningkatkan kinerja keuangan perusahaan. Seiring dengan meningkatnya kinerja keuangan perusahaan 
maka investor akan merespon baik perusahaan dengan menghargai nilai saham perusahaan lebih tinggi bila dibandingkan dengan nilai bukunya.

Pengalaman dan pengetahuan di bidang ekonomi dan bisnis yang dimiliki oleh dewan komisaris dapat membantu mereka dalam memaksimalkan pengendalian dalam hal menghindari perusahaan dari kecurangan dalam pelaporan keuangan.Hasil penelitian ini sejalan dengan hasil penelitian Roma (2012) yang menemukan bahwa kompetensi dewan komisaris berpengaruh positif terhadap probabilitas perusahaan untuk dinilai lebih tinggi oleh investor, serta penelitian yang dilakukan oleh Darmadi (2013) menemukan bahwa latar belakang pendidikan dari anggota dewan berpengaruh terhadap kinerja perusahaan, pada tingkat tertentu. Penelitian oleh Wiwik, et al. (2007) juga menemukan bahwa kompetensi dan independensi dewan komisaris berpengaruh positif terhadap pelaksanaan good corporate governance.Perusahaan yang dipimpin oleh dewan komisaris berkompetensi dibidang ekonomi dan bisnis, maka probabilitas perusahaan untuk dinilai lebih tinggi oleh investor akan semakin tinggi. Dewan komisaris yang berkompeten dapat mempertimbangkan keputusan berdasarkan pengetahuan ekonomi dan bisnis yang dimilikinya, sehingga dapat lebih berhati-hati dalam mengambil keputusan yang bertujuan untuk memperketat pengawasan terhadap kinerja dewan direksi. Pengawasan yang ketat dapat membantu kinerja dewan direksi berjalan lebih efektif dan efisien, sehingga kinerja keuangan perusahaan jugaakan semakin baik. Kinerja perusahaan yang baik akan menghasilkan laporan keuangan yang sehatsehingga perusahaan akan mendapat respon yang positif dari para investor dalam bentuk nilai 
saham yang bisa lebih tinggi dibandingkan dengan nilai buku perusahaan.

Koefisien regresi kualitas auditor adalah sebesar 0,121 dengan nilai signifikansi sebesar0,005 (kurang dari 0,05), maka $\mathrm{H}_{3}$ diterima. Hal ini berarti terdapat pengaruh antara variabel kualitas auditor pada perubahan variabel nilai perusahaan (Tobin's Q).Koefisien regresi kualitas auditor bertanda positif berarti perusahaan yang laporan keuangannya diaudit oleh KAP Big 4akan mengalami peningkatan nilai perusahaan sebesar 0,121 . Kantor akuntan besar memiliki jumlah klien yang banyak sehinggaakan berusaha mempertahankan reputasinya dengan menghasilkan kualitas audit yang lebih baik. Watts dan Zimmerman (1986) menyatakan bahwa faktor ukuran KAP berpengaruh terhadap kualitas audit.Berdasarkan teori signaling, perusahaan akan memberikan sinyal kepada para investor atas keberhasilan atau kegagalan perusahaan yang dijalankannya. Dalam hal ini, kualitas auditor dapat menjadi sinyal positif ataupun negatif. Hussainey (2009) menyatakan bahwa kualitas laporan keuangan yang diaudit oleh kantor akuntan besar lebih berkualitas tinggi dibandingkan dengan kualitas laporan keuangan yang diaudit oleh kantor akuntan publik biasa, sehingga umumnya investor akan bereaksi positif bila laporan keuangan suatu perusahaan diaudit oleh KAP Big 4. Laporan keuangan yang diaudit oleh kantor akuntan publik besar (KAP Big 4) lebih dipercaya para investor karena auditor akan lebih berhati-hati dalam melakukan proses audit dalam mendeteksi kecurangan untuk mempertahankan kredibilitas dan reputasinya.

Hasil penelitian ini sejalan dengan hasil penelitian Ardiana (2014) menunjukkan pengaruh positif ukuran KAP terhadap nilai perusahaan.Laporan 
keuangan yang diaudit oleh kantor akuntan publik besar (KAP Big 4) lebih dipercaya para investor karena menganggap bahwa untuk mempertahankan kredibilitasnya, auditor akan lebih berhati-hati dalam melakukan proses audit untuk mendeteksi kecurangan. Semakin tinggi kualitas auditor maka akan meningkatkan kredibilitas dari laporan keuangan, yang nantinya berpengaruh terhadap harga saham perusahaan. Harga saham yang tinggi akan meningkatkan nilai perusahaan.

Uji koefisien determinasi digunakan untuk menguji goodness-fit dari model regresi. Hasil uji koefisien determinasi dapat dilihat pada Tabel 3. Berdasarkan hasil tersebut, diperoleh angka Adjusted $R$ Square yaitu 0,127 atau sama dengan 12,7 persen yang artinya pengaruh variabel independen yaitu kepemilikan institusional, kompetensi dewan komisaris, kualitas auditor terhadap variabel dependen yaitu nilai perusahaan (Tobin's Q) sebesar 12,7 persen, sedangkan sisanya sebesar 87,3 persen dijelaskan oleh variabel lain yang tidak dimasukkan ke dalam model.

Uji $\mathrm{F}$ bertujuan untuk menguji kelayakan dari suatu model regresi berganda.Apabila nilai signifikansi lebih kecil dari 0,05 maka dapat dikatakan model penelitian dapat atau layak digunakan. Berdasarkan hasil analisis pada Tabel 3, dapat dilihat bahwa nilai signifikansi $\mathrm{F}$ adalah 0,000 atau lebih kecil dari 0,05 sehingga dapat disimpulkan model ini layak digunakan dalam penelitian.

\section{SIMPULAN DAN SARAN}

Simpulan dalam penelitian ini yaitu kepemilikan institusional berpengaruh positif pada nilai perusahaan. Semakin tinggi kepemilikan institusional maka 
pengawasan eksternal terhadap perusahaan akan semakin kuat. Kepemilikan institusional akan mendorong peningkatan pengawasan terhadap kinerja perusahaan dalam mencapai tujuan perusahaan yaitu mengoptimalkan nilai perusahaan. Kompetensi dewan komisaris berpengaruh positif pada nilai perusahaan.Dewan komisaris yang memiliki pengalaman dan pengetahuan di bidang ekonomi dan bisnis dapat melakukan pengendalian secara efektif, sehingga dapat meningkatkan kualitas pelaporan keuangan. Pelaporan keuangan yang baik dan transparan dapat mengundang respon positif dari para investor, sehingga nilai perusahaan akan meningkat. Kualitas auditor berpengaruh positif pada nilai perusahaan.Laporan keuangan yang diaudit oleh KAP Big 4 lebih dipercaya para investor. Untuk mempertahankan kredibilitasnya, auditor KAP Big 4akan lebih berhati-hati dalam melakukan proses audit. Semakin tinggi kualitas auditor maka akan meningkatkan kredibilitas dari laporan keuangan dan akan berpengaruh terhadap harga saham perusahaan yang sekaligus dapat meningkatkan nilai perusahaan.

Beberapa keterbatasan mempengaruhi hasil penelitian dan perlu menjadi bahan pengembangan pada penelitian selanjutnya. Saran-saran yang dapat disampaikan berdasarkan penelitian ini adalah sebagai berikut:

1) Nilai koefisien determinasi (adjusted $\mathrm{R}^{2}$ ) sebesar 0,127 atau 12,7 persen hal ini berarti 12,7 persen variasi nilai perusahaan (Tobin's Q) yang bisa dijelaskan oleh variasi dari ketiga variabel independen yaitu kepemilikan institusional, kompetensi dewan komisaris, dan kualitas auditor. Sedangkan sisanya sebesar 87,3 persen dijelaskan oleh variabel-variabel lain di luar model penelitian. Hal ini 
berarti masih ada variabel lain yang perlu diidentifikasikan untuk menjelaskan nilai perusahaan. Variabel lain yang secara teoritis mungkin dapat mempengaruhi nilai perusahaan seperti kebijakan deviden, profitabilitas, likuiditas, ukuran perusahaan dan pertumbuhan perusahaan. Oleh sebab itu, penelitian berikutnya dapat mempertimbangkan variabel tersebut dan dapat diuji dengan teknik analisis yang berbeda.

2) Penelitian ini hanya dilakukan pada perusahaan manufaktur yang terdaftar di Bursa Efek Indonesia, penelitian berikutnya dapat dilakukan pada objek yang berbeda misalnya perusahaan sektor keuangan maupun sektor pertambangan untuk memperoleh konsistensi hasil penelitian.

\section{REFERENSI}

Ardiana, Putu Agus. 2014. The Role of External Audit in Improving Firm's Value: Case of Indonesia. Proceeding. The 5th International Conference of The Japanese Accounting Review.Kobe 21 Desember.

BAPEPAM. 2002. Kasus Manipulasi PT Kimia Farma Tbk. Diakses dari: URL: http://www.bapepam.go.id.

Borolla, Johanis Darwin. 2011. Analisis Pengaruh Struktur Kepemilikan Terhadap Nilai Perusahaan. Jurnal Prestasi. 7(1).

Christiawan, Yulius Jogi. 2003. Kompetensi dan Independensi Akuntan Publik: Refleksi Hasil Penelitian Empiris. Jurnal Akuntansi dan Keuangan.4(2).

Darmadi, Salim. 2013. Board Members' Education and Firm Performance: Evidence from a Developing Economy. International Journal of Commerce and Management. 23(2): 113-135.

DeAngelo, L.E. 1981. Auditor Size and Audit Quality. Journal of Accounting and Economics. 183-199. 
Dewata, Evada, L.Vera Riama, Henny Yulsiati, dan Sandrayati. 2015. Pengaruh Board Size dan Kualitas Audit Terhadap Nilai Perusahaan Tambang Batubara yang Terdaftar Di BEI. Simposium Nasional Akuntansi 18 Universitas Sumatera Utara, Medan. 16-19 September.

Ghozali, Imam. 2014. Aplikasi Analisis Multivariate dengan Program SPSS. Semarang : Badan Penerbit Universitas Diponegoro.

Haruman, T. 2008.Pengaruh Struktur Kepemilikan terhadap Keputusan Keuangan dan Nilai Perusahaan.Simposium Nasional Akuntansi XI.

Hastuti, D. T. 2005.Hubungan Antara Good Corporate Governance dan Struktur Kepemilikan Dengan Kinerja Keuangan.Simposium Nasional Akuntansi VIII Solo. 475-490.

Hussainey, K. 2009. The Impact of Audit Quality on Earnings Predictability.Managerial Auditing Journal. 24(4): 340-351.

Ismiyanti, Fitri dan Mamduh, M. Hanafi. 2004. Struktur Kepemilikan, Risiko, dan Kebijakan Keuangan: Analisis Persamaan Simultan. Jurnal Ekonomi dan Bisnis Indonesia. 19(2): 176-196.

Jensen, M. C. dan Meckling, W. H. 1976. Theory of Firm: Managerial Behavior, Agency Cost and Ownership Structure. Journal of Financial Economics.3: 305-360.

Juliardi, Dodik. 2013. Pengaruh Leverage, Konsentrasi Kepemilikan dan Kualitas Audit terhadap Nilai Perusahaan Serta Laba Persistensi (Studi Perbandingan antara Perusahaan-perusahaan Manufaktur yang Diaudit KAP 4 Besar dan KAP Non 4 Besar). Jurnal Akuntansi Aktual. 2(2): 113-122.

Kusumastuti, S., Supatmi, dan Sastra, P. 2007. Pengaruh Board Diversity terhadap Nilai Perusahaan dalam Perspektif Corporate Governance. Jurnal Akuntansi dan Keuangan. 9(2): 88-98.

Koetin, E. A. 1997.Analisis Pasar Modal Indonesia. Jakarta: Pustaka Sinar Harapan.

Lanfranconi, CP. dan Robertson DA. 2002. Corporate Financial Reporting: The Role of The Board Directors. Ivey Business Journal. 67 (1): 1-3.

Mayangsari, S. 2004. Bukti Empiris Pengaruh Spesialisasi Industri Auditor terhadap Earning Response Coefficient.Jurnal Riset Akuntansi. 7(2):154-178. 
Nuraina, E. 2012.Pengaruh Kepemilikan Institusional dan Ukuran Perusahaan Terhadap Kebijakan Hutang dan Nilai Perusahaan.Jurnal Bisnis dan Ekonomi.19: 110-125.

Ratnadi, Ni Made Dwi dan Ulupui, I Gusti Ketut Agung. 2016. Pengaruh Konsentrasi Kepemilikan dan Kompetensi Dewan Komisaris pada Konservatisma Akuntansi. Jurnal Akuntansi. 20(1): 1-15.

Ross, S. 1977. The Determination of Financial Structure: the Icentive Signalling Approach.Bell Journal of Economics. 8: 23-40

Roma, D. 2012. Pengaruh Kompetensi Dewan Komisaris, Proporsi Dewan Komisaris Independen, dan Frekuensi Rapat Dewan Komisaris terhadap Nilai Perusahaan. Diakses dari: URL: http://repository.uksw.edu/handle/123456789/2647.

Subekti, I., Wijayanti, A., dan Akhmad, K. 2010. The Real and Accruals Earnings Management: Satu Perspektif dari Teori Prospek. Simposium Nasional Akuntansi XIII Purwokerto. 1-42.

Sugiyono. 2014. Memahami Penelitian Kualitatif. Bandung: Alfabeta.

Sukamulja dan Sukmawati. 2004. Good Corporate Governance di Sektor Keuangan: Dampak GCG terhadap Perusahaan. BENEFIT. 8(1): 1-25.

Sukirni, Dwi. 2012. Kepemilikan Manajerial, Kepemilikan Institusional, Kebijakan Deviden dan Kebijakan Hutang Analisis terhadap Nilai Perusahaan. Accounting Analysis Journal. 1(2).

Sofyaningsih, Sri dan Hardiningsih, Pancawati. 2011. Struktur Kepemilikan, Kebijakan Dividen, Kebijakan Utang dan Nilai Perusahaan. Dinamika Keuangan dan Perbankan Universitas Stikubank. 3(1): 68-87.

Wahyudi, Untung dan Prasetyaning, Hartini Pawestri. 2005. Implikasi Struktur Kepemilikan terhadap Nilai Perusahaan: Dengan Keputusan Keuangan Sebagai Variabel Intervening. Simposium Nasional Akuntansi IX. Padang 2326 Agustus.

Watts, R, L., dan Zimmerman, J, L. 1986.Positive Accounting Theory. New York: Prentice Hall. 
Cok Istri Ratna Sari Dewi, Ni Made Dwi Ratnadi dan Maria M. Ratna. Pengaruh Kepemilikan...

Wiwik, Andriani, Sukartini, dan Reno Fithri Meuthia. 2007. Pengaruh Kompetensi dan Independensi Dewan Komisaris terhadap Pelaksanaan Good Corporate Governance. Jurnal Akuntansi dan Manajemen.2(2). 